\title{
Data report: semiquantitative determination of detrital input to ACEX sites based on bulk sample X-ray diffraction data'
}

\author{
Christoph Vogt ${ }^{2}$
}

\section{Chapter contents}

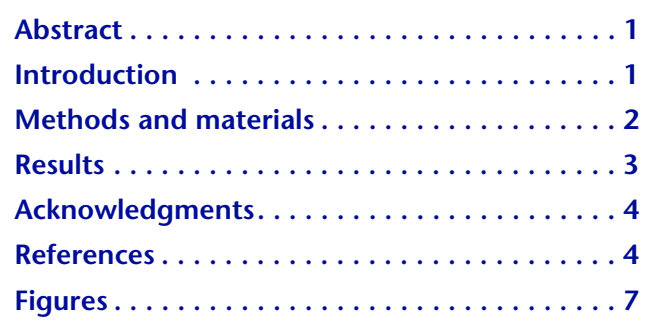

${ }^{1}$ Vogt, C., 2009. Data report: semiquantitative determination of detrital input to ACEX sites based on bulk sample X-ray diffraction data. In Backman, J., Moran, K., Mclnroy, D.B., Mayer, L.A., and the Expedition 302 Scientists, Proc. IODP, 302: Edinburgh (Integrated Ocean Drilling Program Management International, Inc.). doi:10.2204/iodp.proc.302.203.2009 ${ }^{2}$ Crystallography and Central Laboratory for Crystallography and Applied Material Sciences (ZEKAM), Geosciences, University of Bremen, Germany, Klagenfurter Strasse 2, D-28359 Bremen, Germany. cvogt@uni-bremen.de
Abstract

This data report extends the X-ray diffraction (XRD) work reported in the Expedition Reports section of this volume from 200 samples to 1570 investigated bulk powder samples. The unique central Arctic Ocean samples of the Integrated Ocean Drilling Program Arctic Coring Expedition (Expedition 302), the first mission-specific platform expedition, were collected and prepared by different German groups and provided to the Central Laboratory for Crystallography and Applied Material Sciences (ZEKAM), Geosciences, University of Bremen. The data set reported here is special because all samples were measured on the same diffractometer using the same measurement settings, and the diffractograms were investigated by the same person. Therefore, the data set gives maximum continuity with the onshore party investigation. The Neogene sediments of the Arctic Ocean are dominated by detrital nonbiogenic material. The composition of fine-fraction silicates (clay minerals), the different $\mathrm{SiO}_{2}$ mineral phases, which dominate much of the Paleogene sections, and the diagenetic overprinting in the whole cores are best deciphered by XRD. Important paleoceanographic and diagenic information were deduced.

\section{Introduction}

The detrital mineral content of Arctic Ocean sediments is one of the major sources of paleoceanographic interpretations because of the scarcity of biogenic tracers, in particular in the Neogene sediments of central Arctic Ocean cores (e.g., Moran et al., 2006; Backman and Moran, 2008; Darby, 2008; Krylov et al., 2008, and references therein). The Integrated Ocean Drilling Program (IODP) Arctic Coring Expedition (ACEX; Expedition 302) cores are situated below the confluence of the two major surface currents of the Arctic Ocean, the Beaufort Gyre and the Transpolar Drift. Intermediate and deep waters of the Amerasian and Eurasian Basin are separated by the Lomonosov Ridge, which rises $>3000 \mathrm{~m}$ above the seafloor (Fig. F1) (Rudels et al., 2004; Jakobsson et al., 2008). Previous work has delineated the major source rocks and tracer mineral assemblages that are related to the diverse mineralogy of the circum-Arctic source regions. Figure F1 (Vogt, 1997, with later additions) summarizes early investigations (Belov and Lapina, 1961; Berry and Johns, 1966; Silverberg, 1972; Naugler et 
al., 1974; Darby, 1975; Clark et al., 1980; Darby et al., 1989; Stein et al., 1994), recent clay (Wahsner et al., 1999; Viscosi-Shirley et al., 2003) and heavy mineral (Behrends et al., 1999) investigations, and the first comprehensive quantification of bulk mineral assemblages (Vogt, 1997).

In general, the Canadian Arctic archipelago is a major source of detritral carbonates and the Putorana flood basalts to the south of the eastern Kara and Western Laptev Sea are the source of a unique smectite, plagioclase, and (clino-)pyroxene mineral assemblage. These regions are also very significant sources of geochemically highly differentiated Fe-oxide mineral assemblages (Darby et al., 2002). Putorana Plateau basalts also produce a unique signal that is detectable in rare earth elements and radionuclide investigations (Eisenhauer et al., 1994, 1999; Tütcken et al., 2002; Haley et al., 2008) as well as in their inorganic geochemistry (Schoster et al., 2000). Investigations of the magnetic properties also traced a specific magnetic mineral assemblage for these basaltic rocks (Kleiber and Niessen, 2000).

Here I extend the initial investigation of the offshore science party to a much higher sample resolution (every few centimeters in the uppermost $60 \mathrm{~m}$, lithologic Unit 1, and between $\sim 190$ and 380 meters below seafloor [mbsf], lithologic Units $1 / 5,1 / 6,2$, and 3) (see the "Sites M0001-M0004" chapter for detailed lithology). Although general trends prevailed (cf. the Expedition Reports section of this volume), much higher frequency changes in the mineral assemblage are observed in the extended data set (Fig. F2). Despite the already high number of samples, I hope to increase the sample resolution in the future. I encourage every research group that possesses ground powder samples of ACEX cores to provide us with their sample sets. Samples would not be destroyed and contamination is at a minimum at our laboratory.

\section{Methods and materials}

Sediment samples were frozen, freeze-dried to remove water, and ground by hand with an agate mortar and pestle (see the "Sites M0001-M0004" chapter) or agate mills (new ZEKAM, AWI, and ICBM Oldenburg sample sets) (see Stein et al., 2006; Sluijs et al., 2008). A few onshore party samples were replicated in the new sample sets. No significant differences in X-ray diffraction (XRD) data from differently ground samples were found. The high number of 1570 investigated samples was only possible through cooperation with R. Stein (Alfred Wegener Institute Bremerhaven, AWI) and H.-J. Brumsack (Institute for Chemistry and Biology of the Sea, University of Oldenburg, ICBM), who provided their Paleogene samples of the ACEX cores (basically between 180 and 430 meters composite depth [mcd]). The upper 60 mcd of the ACEX cores was sampled by the author.

\section{X-ray diffraction}

\section{Instrument parameters}

All 1570 XRD measurements were performed at the Crystallography Department of Geosciences, University of Bremen, on a Philips X'Pert Pro MD X-ray diffractometer equipped with a $\mathrm{Cu}$ tube $\left(\mathrm{K}_{\alpha}, \lambda 1.541\right)$, a fixed divergence slit $\left(1 / 4^{\circ} 2 \theta\right)$, a 15 -sample changer, a secondary monochromator, and the $\mathrm{X}^{\prime}$ Celerator detector system. Samples were prepared with the standardized Philips/Panalytical backloading system, which provides nearly random distribution of the particles. Measurements were made from $3^{\circ}$ to $85^{\circ} 2 \theta$ with a calculated step size of $0.016^{\circ} 2 \theta$. The calculated time per step was $100 \mathrm{~s}$. The 1570 samples needed $\sim 1700 \mathrm{~h}$ measuring time on our XRD instrument. This time would increase to at least $\sim 5100 \mathrm{~h}$ ( 212 days/24 h running) on a standard XRD instrument with scintillation detector, and thus consume very much of the mean lifetime of a standard X-ray tube.

Peak identification was done graphically through the Apple MacIntosh program MacDiff (version 4.5) (servermac.geologie.uni-frankfurt.de/Staff/Home pages/Petschick/RainerE.html) (Petschick et al., 1996). To minimize subjective influences, the baseline has been determined automatically with MacDiff defaults. The program also provides a mechanism to automatically estimate the integrated peak area intensities with given defaults (for example, by deconvolution of nearby peaks), as many other XRD data programs do. I do not recommend these "black boxes" for any kind of single peakbased investigations, as natural mixtures of mixed elemental silicates like clay minerals, feldspars, and so on, are too variable to be accurately identified by these automatic routines. In particular, the peak position and ranges of a certain peak or group of peaks are too variable in different samples even from the same region or core (for example, between the Neogene and the Paleogene section of the ACEX cores). This means that the recognition of peaks and the calculation of integrated peak areas is a matter of a certain amount of subjectivity, though that can be 
minimized, and that is why I emphasize here that all 1570 samples have been investigated by one person.

\section{Mineral identification and semiquantification}

Integrated peak area intensities for the 38 investigated mineral peaks were calculated by MacDiff. Based on these areas, ratios were calculated versus each other and versus the sum of all peak area intensities. To provide an easy comparison to published data on surface samples of the potential source regions (Andersen et al., 1996; Vogt, 1997; Vogt et al., 2001), the fixed divergence was changed to automatic divergence using an algorithm integrated in MacDiff. This point is important to note, as a fixed divergence slit leads to a stronger radiation of the lowest angles (Fischer, 1996). If single peaks are investigated at these low angles, the higher radiation leads to higher peaks and to higher content percentages (see Krylov et al., 2008, for a comparison of fixed divergence and automatic divergence slit measurements and the content of the smectite group of the clay fraction). Whereas mineral content trends stay the same over the core, absolute values differ, and a comparison of these absolute numbers between an XRD data set measured with fixed and another measured with automatic divergence slit would lead to difficulties in comparing results.

I also did not multiply the peak area data by any kind of factor (e.g., Schultz, 1964; Griffin, 1971; Ramm, 1991), as (1) the chemistry and mineralogy of Arctic Ocean sediments are different from the rocks investigated by these authors and the factors might be completely wrong, (2) a comparative work similar to Schultz (1964) for Arctic Ocean source region materials is pending (see Forsberg et al., 1999), and (3) the use of different factors in various publications leads to content percentages that cannot be compared to each other at all. In general, single peak data produce the highest quantification error, as can be seen by interlaboratory comparisons (cf. Omotoso et al., 2006, and references therein).

The latest point is illustrated by Figure F3. Vogt (1997) used the calculation factors of the four different popular ways of calculating the clay mineral assemblage composition in Arctic Ocean sediments. Massive differences appear, particularly in the content of kaolinite and chlorite, because the peak intensities selected for chlorite depend directly on the Fe content in the chlorites (illustrated by the peak intensity ratio 4.72/3.54 $\AA$ in Fig. F3) (see Brown and Brindley, 1980). At this point even the trends in clay mineral group contents differ. Comparison of such different initial data could lead to a misinterpreta- tion, particularly in overview articles that do not check for the initial semiquantification technique (e.g., Dethleff, 2005).

Absolute intensities also depend on the general XRD instrument configuration, the radiation source, and the sample preparation methodology. Therefore, d-values and ratios of intensities for the investigated peaks versus the total intensity of the investigated samples are given in the results table in the PANGAEA/WDC Mare database (doi.pangaea.de/10.1594/PANGAEA.705057). I propose that these ratios are easier to compare between different XRD instruments. I recommend Kahle et al. (2002) along with Moore and Reynolds (1997) for further reading about the use of single peak intensities for semiquantification.

In our laboratory we also use the Philips/Panalytical software X'Pert HighScore for fast identification of mineral phases. Based on a vast reference database, the software also gives a semiquantitative estimate for each identified mineral on the basis of the relative intensity ratio (R.I.R.) values. These R.I.R. values are calculated as intensity ratio of the most intense reflex of a specific mineral phase to the intensity of the most intense reflex of pure corundum $\left(I / I_{c}\right)$ referring to the "matrix-flushing method" after Chung (1974). Therefore, the availability of suitable references in the database with correct R.I.R. is crucial. Hence, only two examples are shown here (Figs. F4, F5), although most of the samples have already been investigated with HighScore.

\section{Results}

On all 1570 samples, peaks for 38 minerals were identified and quantified on XRD traces. The sum of all peak areas was calculated as a "total peak area" (TPA) (Fig. F2). Data are presented in the same manner as in the "Sites M0001-M0004" chapter. Presenting the ratio of a given mineral peak versus TPA also excludes the dilution of the noncrystalline materials, which produces a diffuse bulb in the background of the diffractogram (compare Fig. F4 and Fig. F5). In the Paleogene sequence, particularly in lithologic Units 2 and 3 of the ACEX cores (see the "Sites M0001-M0004" chapter), this is represented by noncrystalline opal-A and partially crystalline opal-CT. The reduction in TPA is here directly related to opal contents up to 60\%-70\% (Ogawa et al., 2008, submitted). In the Neogene section of the ACEX cores, small amounts of amorphous Fe- and Mn-oxides can be assumed, as outlined by the inorganic geochemistry data (see the "Methods" chapter).

The Expedition 302 scientists (see the "Sites M0001M0004" chapter) already chose some very indicative intensity peak ratios, such as the ratios of plagioclase 
and K-feldspar and of kaolinites and chlorites for tracing wet or dry, warm or cold chemical (wet and warm $=$ more kaolinite and less feldspars, less K-feldspar), and strong or weak physical weathering (Griffin et al., 1968; Tucker, 1988). Both ratios have a clear maximum during the warmer phases of the Paleogene sequence (Fig. F2).

Primary or nondiagenetic carbonate minerals (especially calcite) occur predominantly in the upper 200 $\mathrm{m}$ of the combined ACEX core sequence and are always a minor component in the Lomonosov Ridge sediment sequence. Nevertheless, in the uppermost $60 \mathrm{~m}$ ( $\sim 4 \mathrm{Ma}$ according to O'Regan et al., 2008b) carbonate minerals continuously increase, with highfrequency changes occurring in the dolomite content (Fig. F6). It is possible that the intensification of the Northern Hemisphere glaciation is reflected by these data. St. John (2008) proposes such intensification based on an increase in ice-rafted debris and coarse fraction content. However, this is only a hypothesis because a full quantification of the mineral content and its integration with grain size, ice-rafted debris, and physical property data is pending (see O'Regan et al., 2008a, for a first glance at such an effort).

This data report can only give a brief insight into the plentifulness of significant changes of the bulk mineral assemblage. Data are stored in the Pangaea WDC Mare Database (doi.pangaea.de/10.1594/PANGAEA.705057) in the same manner data were tabulated in the site chapter (Table T42 in the "Sites M0001-M0004"chapter). Normalizing the single peak data to the TPA allows for a good interlaboratory comparability and reliable semiquantification of XRD data as long as the configuration of the instruments is similar (i.e., same radiation, same divergence slits, and similar detector). We will complete full quantification of mineral contents for geochemical and paleoceanographic purposes using the QUAX full-pattern analysis software (cf. Vogt et al., 2002).

\section{Acknowledgments}

Financial support was provided by Deutsche Forschungsgemeinschaft (DFG, Funds Fi442/10-1,2) in the German IODP Special Research Program (www.bgr.bund.de/cln_101/nn_332102/DE/

Themen/MeerPolar/IODP/Koordinationsbuero/ DFG_Projekte/dfg_projekte_node.html?_nnn =true). This research was conducted with samples and data from the Integrated Ocean Drilling Program (IODP), an international marine research program dedicated to advancing scientific understanding of the Earth, the deep biosphere, climate change, and Earth processes by sampling and monitoring subseafloor environments. I thank Hans-Jürgen Brumsack (ICBM Oldenburg) and Ruediger Stein (AWI Bremerhaven) for sending their powdered sample sets. I also thank the IODP Bremen Core Repository staff, in particular Walter Hale and Alex Wülbers, for their continuous support and interest during sampling. Thanks also to the onshore Scientific Party and the postcruise scientists for enlightening discussions at the postcruise meeting in Erice, Sicily. I thank the reviewer Claus-Dieter Hillenbrand for a very constructive review and Gigi Delgado for IODP-related matters.

\section{References}

Andersen, E.S., Dokken, T.M., Elverhøi, A., Solheim, A., and Fossen, I., 1996. Late Quaternary sedimentation and glacial history of the western Svalbard continental margin. Mar. Geol., 133(3-4):123-156. doi:10.1016/ 0025-3227(96)00022-9

Backman, J., and Moran, K., 2008. Introduction to special section on Cenozoic paleoceanography of the central Arctic Ocean. Paleoceanography, 23(1):PA1S01. doi:10.1029/2007PA001516

Behrends, M., Hoops, E., and Peregovich, B., 1999. Distribution patterns of heavy minerals in Siberian rivers, the Laptev Sea and the eastern Arctic Ocean: an approach to identify sources, transport and pathways of terrigenous matter. In Kassens, H., Bauch, H.A., Dmitrenko, I.A., Eicken, H., Hubberten, H.W., Melles, M., Thiede, J., and Timokhov, L.A. (Eds.), Land-Ocean Systems in the Siberian Arctic: Dynamics and History: Berlin (Springer-Verlag), 265-286.

Belov, N.A., and Lapina, N.N., 1961. Donnye otlozheniya Arkticheskogo basseina (Bottom Sediments of the Arctic Ocean): Leningrad (Gidrometeoizdat).

Berner, H., and Wefer, G., 1994. Clay-mineral flux in the Fram Strait and Norwegian Sea. Mar. Geol., 116(34):327-345. doi:10.1016/0025-3227(94)90049-3

Berry, R.W., and Johns, W.D., 1966. Mineralogy of the claysized fractions of some North Atlantic-Arctic Ocean bottom sediments. Geol. Soc. Am. Bull., 77(2):183-196. doi:10.1130/0016-7606(1966)77[183:MOTCFO] 2.0.CO;2

Biscaye, P.E., 1964. Distinction between kaolinite and chlorite in recent sediments by X-ray diffraction. Am. Miner., 49:1281-1289.

Biscaye, P.E., 1965. Mineralogy and sedimentation of recent deep-sea clay in the Atlantic Ocean and adjacent seas and oceans. Geol. Soc. Am. Bull., 76(7):803-831. doi:10.1130/0016-7606(1965)76[803:MASORD] 2.0.CO;2

Brown, G., and Brindley, G.W., 1980. X-ray diffraction procedures for clay mineral identification. In Brindley, G.W., and Brown, G. (Eds.), Crystal Structures of Clay 
Minerals and Their X-ray Identification. Mineral. Soc. Monogr., 5:305-359.

Clark, D.L., Whitman, R.R., Morgan, K.A., and Mackay, S.D., 1980. Stratigraphy and glacial marine sediments of the Amerasian Basin, central Arctic Ocean. Spec. Pap.Geol. Soc. Am., 181.

Chung, F.H., 1974. Quantitative interpretation of X-ray diffraction patterns of mixtures, I. Matrix-flushing method for quantitative multicomponent analysis. $J$. Appl. Crystallogr., 7(6):519-525. doi:10.1107/ S0021889874010375

Darby, D.A., 1975. Kaolinite and other clay minerals in Arctic Ocean sediments. J. Sediment. Petrol., 45:272-279.

Darby, D.A., 2008. Arctic perennial ice cover over the last 14 million years. Paleoceanography, 23(1):PA1S07. doi:10.1029/2007PA001479

Darby, D.A., Bischof, J.F., Spielhagen, R.F., Marshall, S.A., and Herman, S.W., 2002. Arctic ice export events and their potential impact on global climate during the late Pleistocene. Paleoceanography, 17(2):1025. doi:10.1029/ 2001PA000639

Darby, D.A., Naidu, A.S., Mowatt, T.C., and Jones, G., 1989. Sediment composition and sedimentary processes in the Arctic Ocean. In Herman, Y. (Ed.), The Arctic Seas: Climatology, Oceanography, Geology, and Biology: New York (van Nostrand Reinhold), 657-720.

Dethleff, D., 2005. Entrainment and export of Laptev Sea ice sediments, Siberian Arctic. J. Geophys. Res., 110(C7):C07009. doi:10.1029/2004JC002740

Eisenhauer, A., Meyer, H., Rachold, V., Tütken, T., Wiegand, B., Hansen, B.T., Spielhagen, R.F., Lindemann, F., and Kassens, H., 1999. Grain size separation and sediment mixing in Arctic Ocean sediments: evidence from the strontium isotope systematic. Chem. Geol., 158(34):173-188. doi:10.1016/S0009-2541(99)00026-1

Eisenhauer, A., Spielhagen, R.F., Frank, M., Hentzschel, G., Mangini, A., Kubik, P.W., Dietrich-Hannen, B., and Billen, T., 1994. ${ }^{10} \mathrm{Be}$ records of sediment cores from high northern latitudes: implications for environmental and climatic changes. Earth Planet. Sci. Lett., 124(1-4):171184. doi:10.1016/0012-821X(94)00069-7

Fischer, R.X., 1996. Divergence slit corrections for BraggBrentano diffractometers with rectangular sample surface. Powder Diffr., 11(1):17-21.

Forsberg, C.F., Solheim, A., Elverhøi, A., Jansen, E., Channell, J.E.T., and Anderson, E.S., 1999. The depositional environment of the western Svalbard margin during the late Pliocene and the Pleistocene: sedimentary facies changes at Site 986. In Raymo, M.E., Jansen, E., Blum, P., and Herbert, T.D. (Eds.), 1999. Proc. ODP, Sci. Results, 162: College Station, TX (Ocean Drilling Program), 233246. doi:10.2973/odp.proc.sr.162.032.1999

Griffin, G.M., 1971. Interpretation of X-ray diffraction data. In Procedures in Sedimentary Petrology: New York (Wiley-Intersci.), 541-569.

Griffin, J.J., Windom, H., and Goldberg, E.D., 1968. The distribution of clay minerals in the World Ocean. DeepSea Res., Part A, 15:433-459.

Haley, B.A., Frank, M., Spielhagen, R.F., and Eisenhauer, A., 2008. Influence of brine formation on Arctic Ocean cir- culation over the past 15 million years. Nat. Geosci., 1(1):68-72. doi:10.1038/ngeo.2007.5

Jakobsson, M., Macnab, R., Mayer, L., Anderson, R., Edwards, M., Hatzky, J., Schenke, H.W., and Johnson, P., 2008. An improved bathymetric portrayal of the Arctic Ocean: implications for ocean modeling and geological, geophysical and oceanographic analyses. Geophys. Res. Lett., 35(4):L07602. doi:10.1029/2008GL033520

Kahle, M., Kleber, M., and Jahn, R., 2002. Review of XRDbased quantitative analyses of clay minerals in soils: the suitability of mineral intensity factors. Geoderma, 109(3-4):191-205. doi:10.1016/S0016-7061(02)001751

Kleiber, H.P., and Niessen, F., 2000. Variations of continental discharge pattern in space and time: implications from the Laptev Sea continental margin, Arctic Siberia. Int. J. Earth Sci., 89(3):605-616. doi:10.1007/ s005310000130

Krylov, A.A., Andreeva, I.A., Vogt, C., Backman, J., Krupskaya, V.V., Grikurov, G.E., Moran, K., and Shoji, H., 2008. A shift in heavy and clay mineral provenance indicates a middle Miocene onset of a perennial sea ice cover in the Arctic Ocean. Paleoceanography, 23(1):PA1S06. doi:10.1029/2007PA001497

Lange, H., 1982. Distribution of chlorite and kaolinite in eastern Atlantic sediments off North Africa. Sedimentology, 29(3):427-431. doi:10.1111/ j.1365-3091.1982.tb01805.x

Moore, D.M., and Reynolds, R.C., Jr., 1997. X-Ray Diffraction and the Identification and Analysis of Clay Minerals (2nd ed.): Oxford (Oxford Univ. Press).

Moran, K., Backman, J., Brinkhuis, H., Clemens, S.C., Cronin, T., Dickens, G.R., Eynaud, F., Gattacceca, J., Jakobsson, M., Jordan, R.W., Kaminski, M., King, J., Koc, N., Krylov, A., Martinez, N., Matthiessen, J., McInroy, D., Moore, T.C., Onodera, J., O’Regan, M., Pälike, H., Rea, B., Rio, D., Sakamoto, T., Smith, D.C., Stein, R., St. John, K., Suto, I., Suzuki, N., Takahashi, K., Watanabe, M., Yamamoto, M., Farrell, J., Frank, M., Kubik, P., Jokat, W., and Kristoffersen, Y., 2006. The Cenozoic palaeoenvironment of the Arctic Ocean. Nature (London, U. K.), 441(7093):601-605. doi:10.1038/nature04800

Naugler, F.P., Silverberg, N., and Creager, J.S., 1974. Recent sediments of the East Siberian Sea. In Marine Geology and Oceanography of the Arctic Seas: New York (Springer Verlag), 191-210.

Ogawa, Y., Takahashi, K., and Yamanaka, T., 2008. Paleoceanography of the middle Eocene Arctic Ocean based on geochemical measurements of biogenic matter. Mem. Fac. Sci., Kyushu Univ., Ser. D: Earth Planet. Sci., 32(1):31-48. http://paleobio.geo.kyushu-u.ac.jp/ memoir/Ogawa et al08.pdf

Ogawa, Y., Takahashi, K., Uehara, S., and Vogt, C., submitted. Biogenic opal in the Eocene sediments from the central Arctic Ocean: refined analytical methodology and significance of the measurements. J. Oceanogr.

Omotoso, O., McCarty, D.K., Hillier, S., and Kleeberg, R., 2006. Some successful approaches to quantitative mineral analysis as revealed by the 3rd Reynolds Cup con- 
test. Clays Clay Miner., 54(6):748-760. doi:10.1346/ CCMN.2006.0540609

O’Regan, M., Frank, M., Haley, B., St. John, K., Backman, J., Moran, K., Vogt, C., Jakobsson, M., King, J., and Ashmankas, C., 2008a. North Atlantic inflow and ice-coverage in the central Arctic Ocean: Neogene records from the Lomonosov Ridge. Geophys. Res. Abstr., 10:EGU2008-A-07844. http://www.cosis.net/ abstracts/EGU2008/07844/EGU2008-A-07844.pdf

O’Regan, M., King, J., Backman, J., Jakobsson, M., Pälike, H., Moran, K., Heil, C., Sakamoto, T., Cronin, T.M., and Jordan, R.W., 2008b. Constraints on the Pleistocene chronology of sediments from the Lomonosov Ridge. Paleoceanography, 23(1):PA1S19. doi:10.1029/ 2007PA001551

Pearson, M.J., and Small, J.S., 1988. Illite-smectite diagenesis and paleotemperatures in northern North Sea Quaternary to Mesozoic shale sequences. Clay Miner., 23(2):109-132. doi:10.1180/claymin.1988.023.2.01

Petschick, R., Kuhn, G., and Gingele, F., 1996. Clay mineral distribution in surface sediments of the South Atlantic: sources, transport, and relation to oceanography. Mar. Geol., 130(3-4):203-229. doi:10.1016/00253227(95)00148-4

Ramm, M., 1991. On quantitative mineral analysis of sandstones using XRD. Intern Skriftser.-Inst. Geol., Univ. Oslo, Norway, 62.

Rudels, B., Jones, E.P., Schauer, U., and Eriksson, P., 2004. Atlantic sources of the Arctic Ocean surface and halocline waters. Polar Res., 23(2):181-208. doi:10.1111/ j.1751-8369.2004.tb00007.x

Sangiorgi, F., Brumsack, H.-J., Willard, D.A., Schouten, S., Stickley, C.E., O’Regan, M., Reichart, G.-J., Sinninghe Damsté, J.S., and Brinkhuis, H., 2008. A 26 million year gap in the central Arctic record at the greenhouse-icehouse transition: looking for clues. Paleoceanography, 23(1):PA1S04. doi:10.1029/2007PA001477

Schoster, F., Behrends, M., Müller, C., Stein, R., and Wahsner, M., 2000. Modern river discharge and pathways of supplied material in the Eurasian Arctic Ocean: evidence from mineral assemblages and major and minor element distribution. Int. J. Earth Sci., 89(3):486-495. doi:10.1007/s005310000120

Schultz, L.G., 1964. Quantitative interpretation of mineralogical composition from X-ray and chemical data for the Pierre shale. U.S. Geol. Surv. Prof. Pap., 391-C.

Silverberg, N., 1972. Sedimentology of the surface sediments of the east Siberian and Laptev Seas [Ph.D. thesis]. Univ. Washington, Seattle.

Sluijs, A., Röhl, U., Schouten, S., Brumsack, H.-J., Sangiorgi, F., Sinninghe Damsté, J.S., and Brinkhuis, H., 2008. Arctic late Paleocene-early Eocene paleoenvironments with special emphasis on the Paleocene-Eocene Thermal Maximum (Lomonosov Ridge, Integrated Ocean Drilling Program Expedition 302). Paleoceanography, 23(1):PA1S11. doi:10.1029/2007PA001495
Stein, R., Grobe, H., and Wahsner, M., 1994. Organic carbon, carbonate, and clay mineral distributions in eastern central Arctic Ocean surface sediments. Mar. Geol., 119(3-4):269-285. doi:10.1016/0025-3227(94)90185-6

Stein, R., Boucsein, B., and Meyer, H., 2006. Anoxia and high primary production in the Paleogene central Arctic Ocean: first detailed records from Lomonosov Ridge. Geophys. Res. Lett., 33(18):L18606. doi:10.1029/ 2006GL026776

St. John, K., 2008. Cenozoic ice-rafting history of the central Arctic Ocean: terrigenous sands on the Lomonosov Ridge. Paleoceanography, 23(1):PA1S05. doi:10.1029/ 2007PA001483

Tucker, M.E., 1988. Techniques in Sedimentology: Oxford (Blackwell Scientific).

Tütken, T., Eisenhauer, A., Wiegand, B., and Hansen, B.T., 2002. Glacial-interglacial cycles in $\mathrm{Sr}$ and $\mathrm{Nd}$ isotopic composition of Arctic marine sediments triggered by the Svalbard/Barents Sea ice sheet. Mar. Geol., 182(34):351-372. doi:10.1016/S0025-3227(01)00248-1

Viscosi-Shirley, C., Mammone, K., Pisias, N., and Dymond, J., 2003. Clay mineralogy and multi-element chemistry of surface sediments on the Siberian-Arctic shelf: implications for sediment provenance and grain size sorting. Cont. Shelf Res., 23(11-13):1175-1200. doi:10.1016/ S0278-4343(03)00091-8

Vogt, C., 1997. Zeitliche und räumliche Verteilung von Mineralvergesellschaftungen in spätquartären Sedimenten des Arktischen Ozeans und ihre Nützlichkeit als limaindikatoren währed der Glazial/ Interglazial-Wechsel (Regional and temporal variations of mineral assemblages in Arctic Ocean sediments as climatic indicator during glacial/interglacial changes). Ber. Polarforschung, 251. http://hdl.handle.net/10013/epic10254

Vogt, C., Knies, J., Spielhagen, R.F., and Stein, R., 2001. Detailed mineralogical evidence for two nearly identical glacial/deglacial cycles and Atlantic water advection to the Arctic Ocean during the last 90,000 years. Global Planet. Change, 31(1-4):23-44. doi:10.1016/S09218181(01)00111-4

Vogt, C., Lauterjung, J., and Fischer, R.X., 2002. Investigation of the clay fraction $(<2 \mu \mathrm{m})$ of the clay mineral society reference clays. Clays Clay Miner., 50(3):388-400. doi:10.1346/000986002760833765

Wahsner, M., Müller, C., Stein, R., Ivanov, G., Levitan, M., Shelekhova, E., and Tarasov, G., 1999. Clay-mineral distribution in surface sediments of the Eurasian Arctic Ocean and continental margin as indicator for source areas and transport pathways-a synthesis. Boreas, 28(1):215-233. doi:10.1080/030094899421272

Initial receipt: 21 August 2008

Acceptance: 27 October 2008

Publication: 5 May 2009

MS 302-203 
Figure F1. Provenance of minerals and mineral groups based on 2000 surface samples quantified with the same XRD measurements and subsequent QUAX determination after Vogt (1997) and Vogt et al. (2002). Qz = dominant, $\mathrm{s}=$ subdominant. Star = approximate ACEX site position. See the "Sites M0001-M0004" chapter for detailed core positions, bathymetry and oceanography. White arrows = downslope sediment transport mainly through troughs. Alm = almandin, $\mathrm{C}_{(\mathrm{Fe})}=$ Fe-rich chlorite, $\mathrm{D}=$ dolomite, $\mathrm{Hbl}=$ hornblende/amphibole, $\mathrm{I}=$ illite/ mica, blue $\mathrm{K}=$ calcite, red $\mathrm{K}=$ kaolinite, $\mathrm{Kfs}=\mathrm{K}$-feldspar, $\mathrm{Mg}=\mathrm{Mg}$-rich calcite, $\mathrm{OLEM}=$ mixed-layer clay, $\mathrm{Plg}=$ Plagioclase, Pyx = pyroxene, Qz = quartz, $\mathrm{S}=$ smectite, $\mathrm{Sid}=$ siderite. $\mathrm{BG}=$ Beaufort Gyre, EGC = East Greenland Current, Lomo $=$ Lomonosov Ridge, $\mathrm{TD}=$ Transpolar Drift, TDsib $=$ Siberian branch, WSC $=$ Westspitzbergen Current.

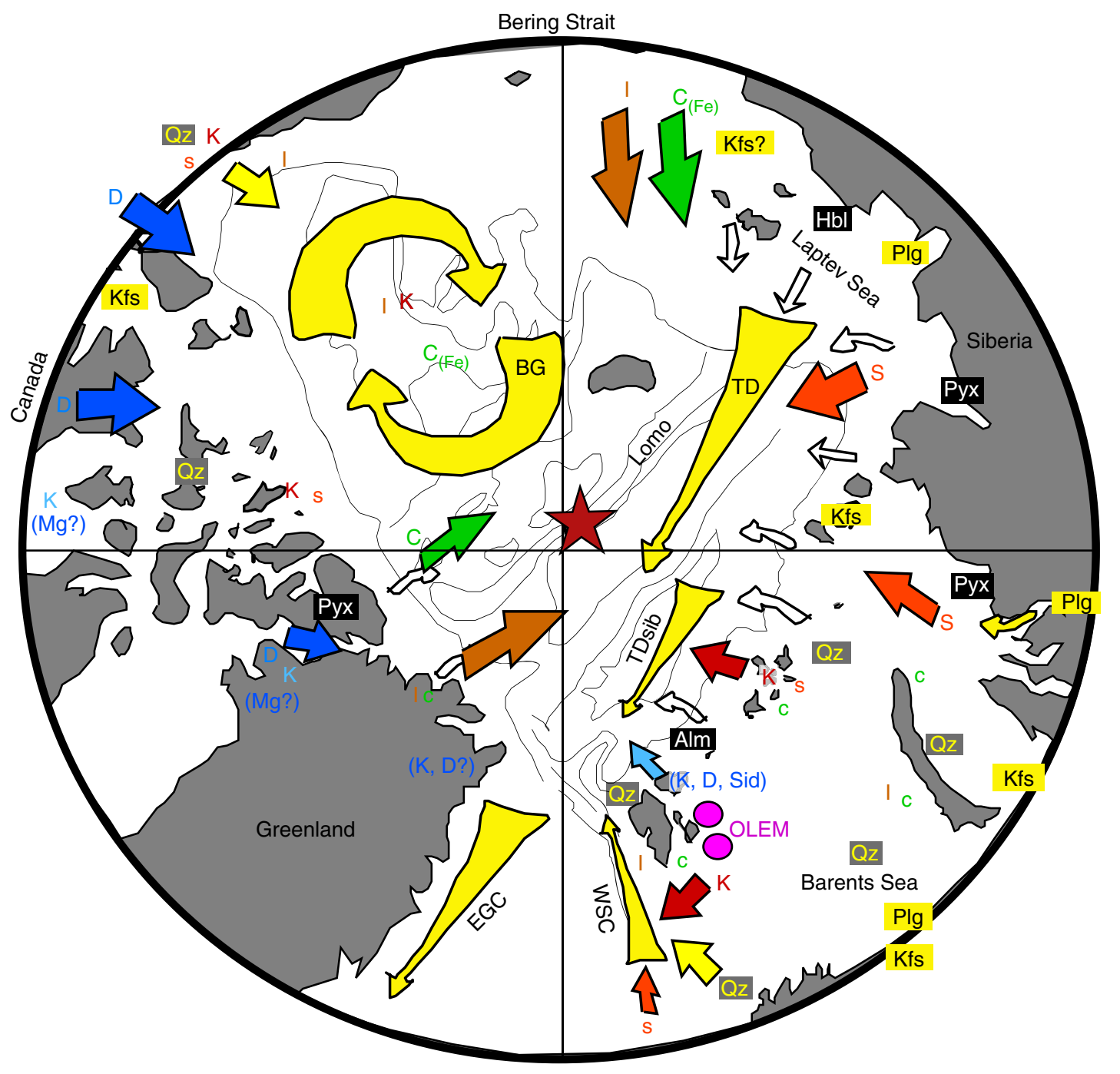


Figure F2. Peak area ratios of quartz (Qz), K-feldspar (Kfs), plagioclase (Plg), kaolinite (K), chlorite (C), and pyrite $(4.26,3.24,3.21,3.58,3.54$, and $2.71 \AA$, respectively). Fsp = sum of feldspar. Pyrite peak area is plotted vs. bulk peak area intensity of 38 investigated XRD peaks (cf. the Expedition Reports section of this volume). Pyrite is predominantly of diagenetic origin. Data available from the Pangaea database (doi.pangaea.de/10.1594/ PANGAEA.705057). Revised depth scale (rmcd) of the combined ACEX cores from O'Reagan et al. (2008a). For a detailed description of the lithologic units $1 / 1$ to $1 / 6,2,3$, and 4, see the "Sites M0001-M0004" chapter. A 26 Ma hiatus exists at $\sim 198$ rmcd (cf. Sangiorgi et al., 2008).

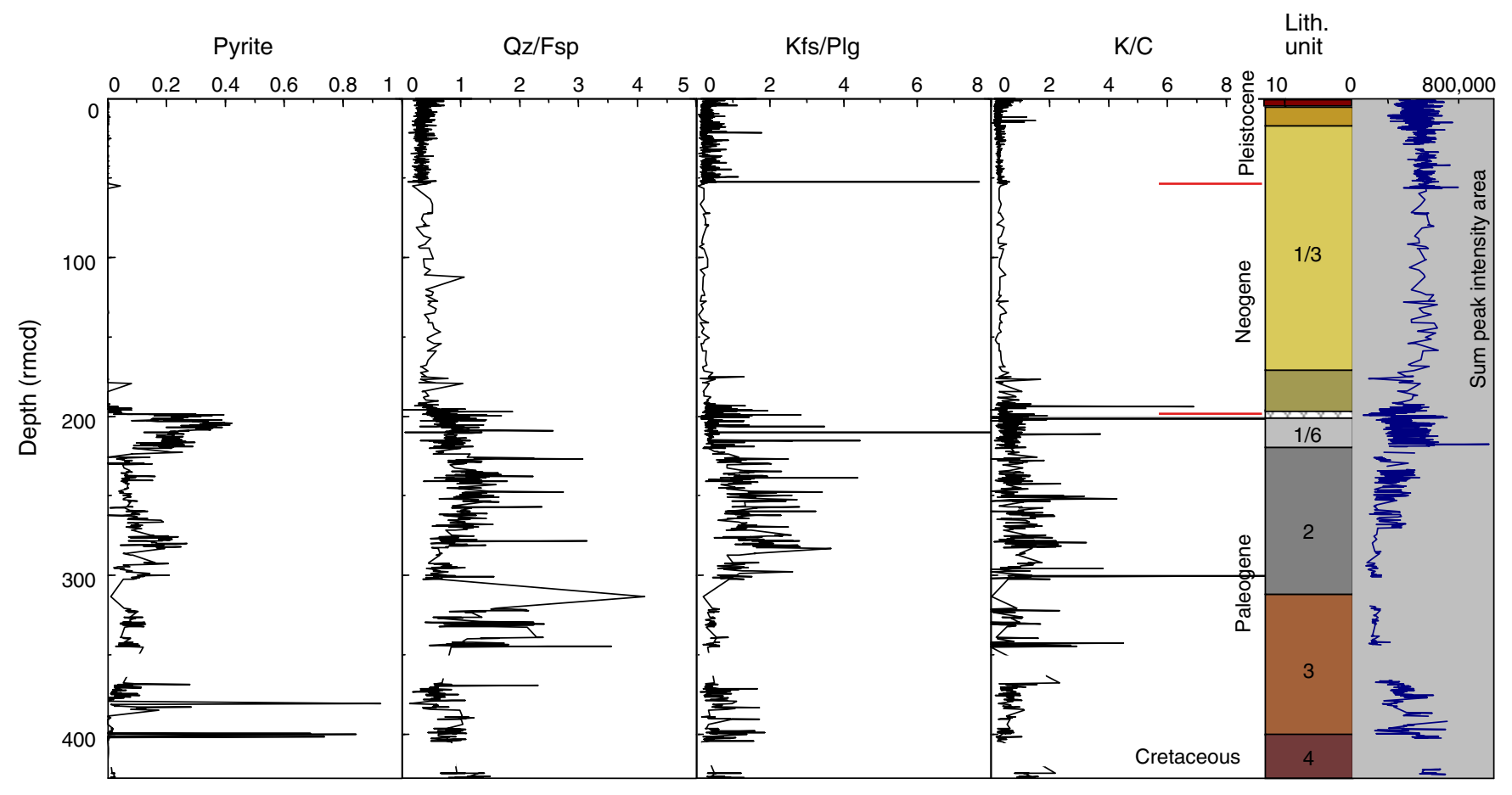


Figure F3. Comparison of four frequently used semiquantitative determinations for the clay mineral assemblages based on single peak intensities (PS2206-4 Gakkel-Ridge, water depth $=2993 \mathrm{~m}$ ). Calculation by Vogt (1997) is based on Biscaye's factors and XRD pattern analysis techniques $(1964,1965)$. Systematic decrease in illite mineral group content calculated after Pearson and Small (1988) is due to the determination of a fifth mineral group, the mixed-layered clays, which is basically deducted from the illite group. MIS = marine isotope stage.
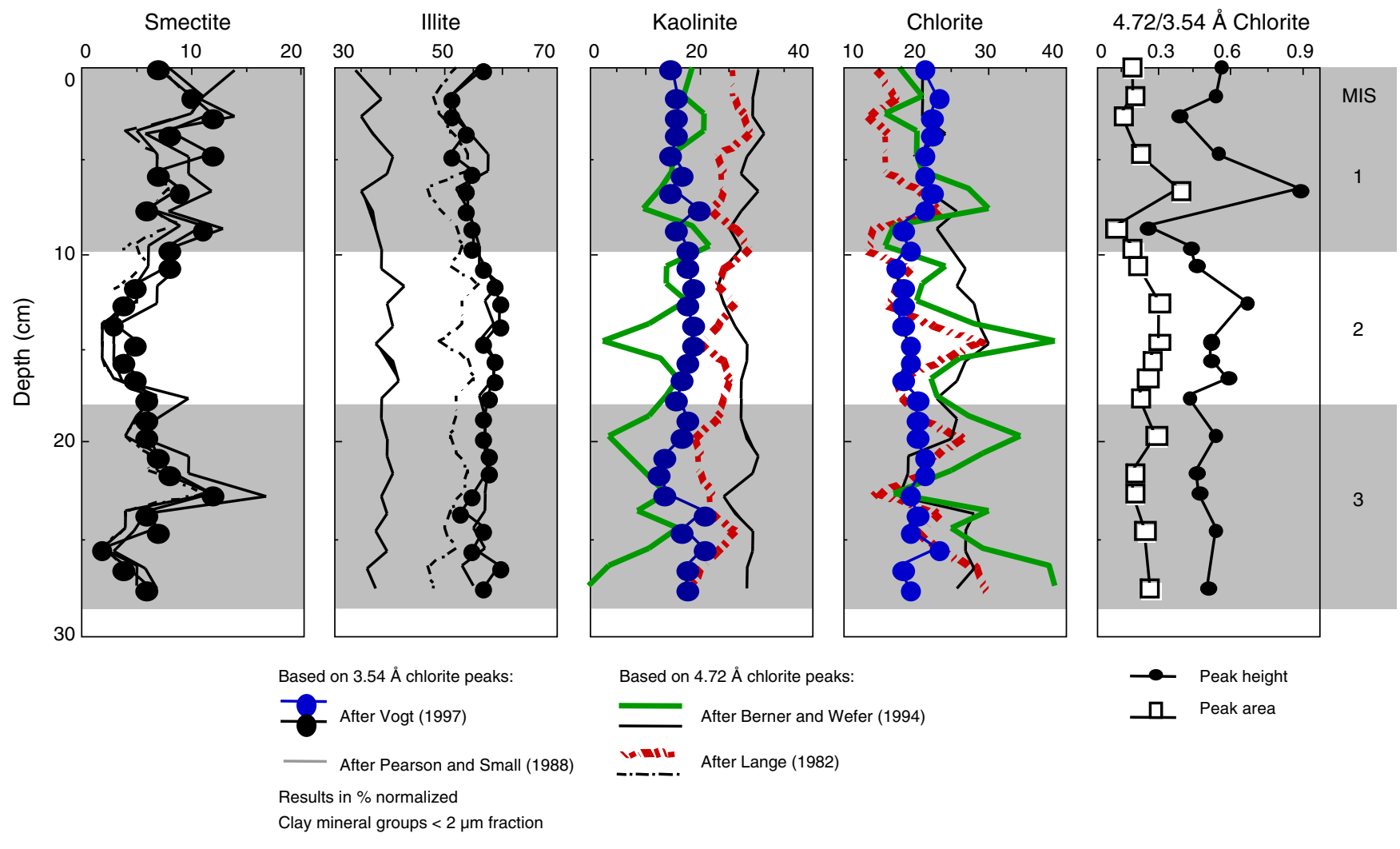
Figure F4. Typical Neogene X-ray pattern (Sample 302-M0002A-5X-2, 5-7 cm). Plots, mineral identification, and semiquantitative estimation of mineral content done with Philips/Panalytical HighScore software.

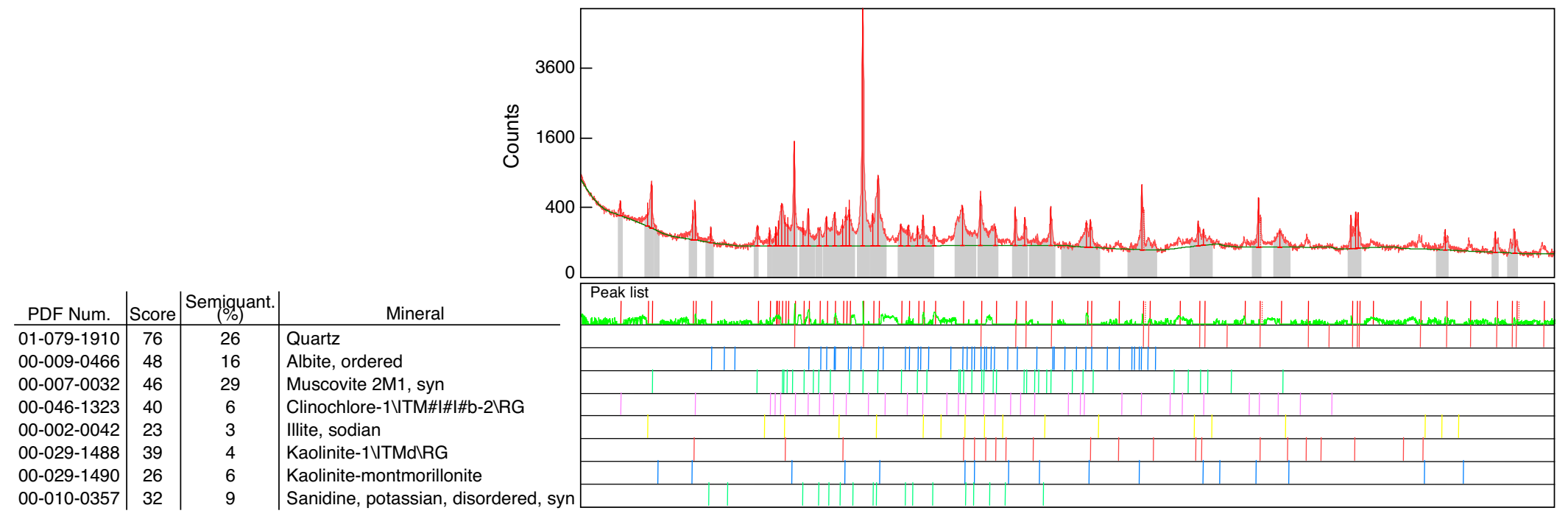


Figure F5. Typical Paleogene X-ray pattern (Sample 302-M0004A-11X-2, $14 \mathrm{~cm})$ with high amounts $(\sim 40 \%)$ of $X$-ray amorphous opal (see bulb below green background line between $20^{\circ}$ and $30^{\circ} 2 \theta$ ). Plots, mineral identification, and semiquantitative estimation of mineral content done with the Philips/Panalytical HighScore software.

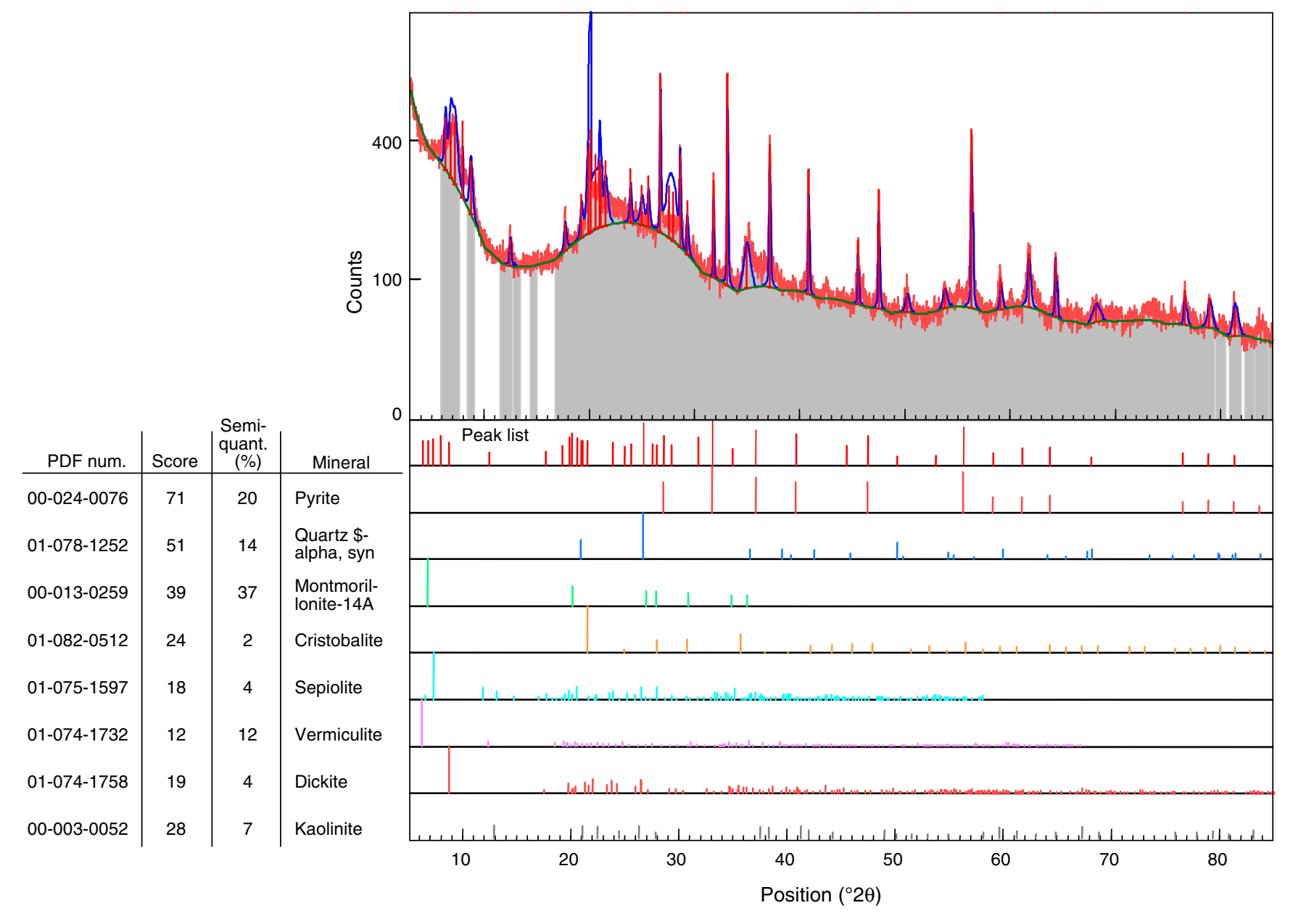


Figure F6. Peak intensity ratios of calcite, dolomite/ankerite, and siderite/magnesite. TPA = total peak area.

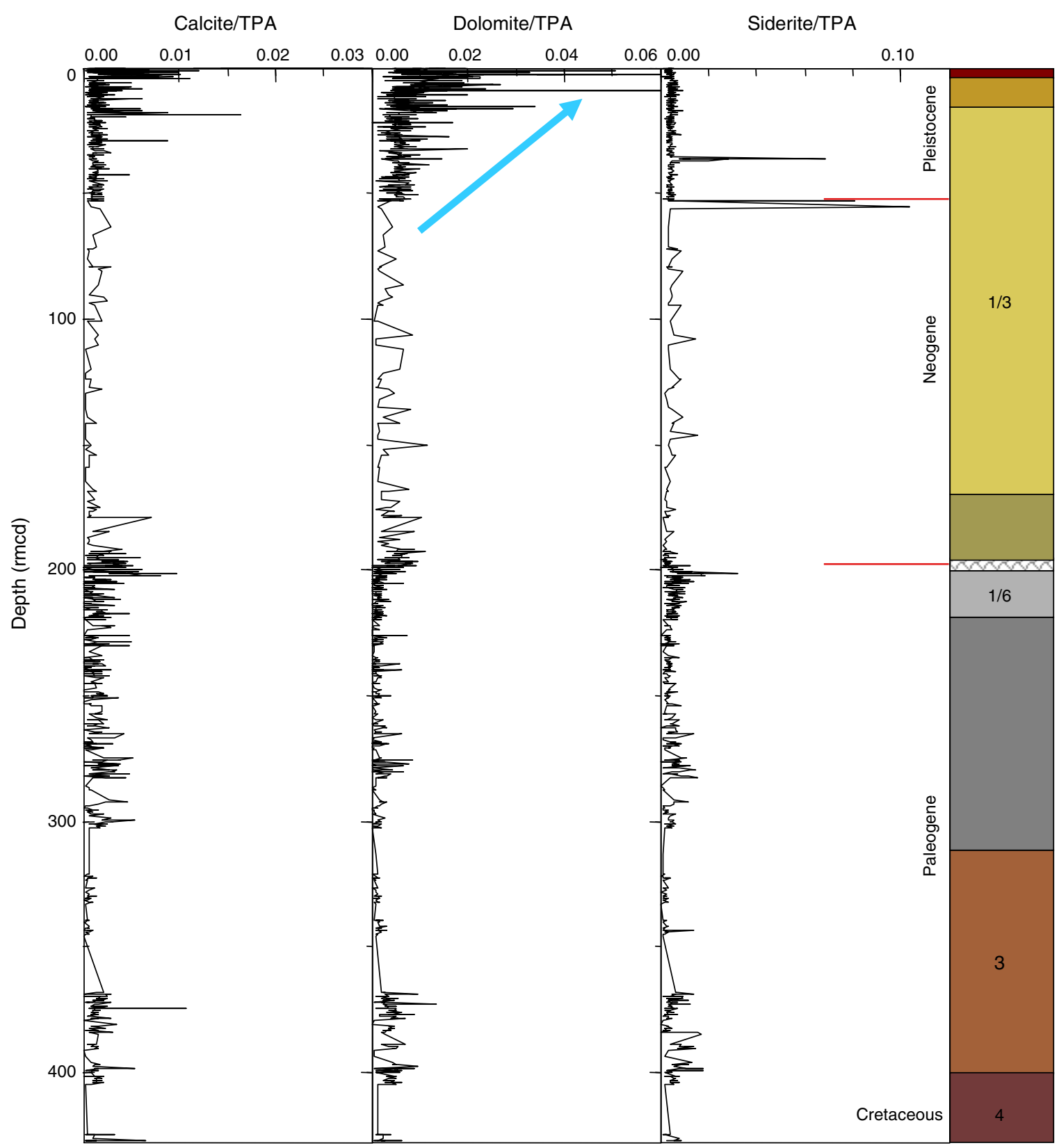

